Jurnal Inkofar * Volume 1 No. 1 Juli 2019 * ISSN: 2615-3645 (Print) / 2581-2920 (Online)

Tersedia secara online di: http://www.politeknikmeta.ac.id/meta/ojs/

\title{
Perancangan Arsitektur Sistem Informasi pada Perguruan Tinggi Menggunakan TOGAF ADM (Studi Kasus: Politeknik Negeri Balikpapan)
}

\author{
Yuyun Tri Wiranti ${ }^{1}$, Nabila Khaerunnisa ${ }^{2}$, Lovinta Happy Atrinawati ${ }^{3}$, Vinda Daningrum ${ }^{4}$ \\ ${ }^{1}$ Sistem Informasi/ Jurusan Matematika dan Teknologi Informasi / Institut Teknologi Kalimantan / \\ yuyun@itk.ac.id \\ ${ }^{2}$ Sistem Informasi/ Jurusan Matematika dan Teknologi Informasi / Institut Teknologi Kalimantan / \\ 10161065@itk.ac.id \\ ${ }^{3}$ Sistem Informasi/ Jurusan Matematika dan Teknologi Informasi / Institut Teknologi Kalimantan / \\ lovinta@itk.ac.id \\ ${ }^{4}$ Sistem Informasi/ Jurusan Matematika dan Teknologi Informasi / Institut Teknologi Kalimantan / \\ vinda.daningrum@itk.ac.id
}

\begin{abstract}
The development of information systems and technology is undeniable resulting in a fierce competition against the organizations that use them. Organizations are competing to improve existing technology to facilitate their activities and increase the selling value of the organization itself. This also applies in the world of education, especially for universities. The higher the level of education, the higher the activity and needs. Various universities try to be the best universities, this can be assessed from the quality of education provided and can not be separated from the facilities offered. For this reason, universities need an information system in managing every activity they run, including Politeknik Negeri Balikpapan (Poltekba). But in developing an information system there is a need to align with the strategy and goals of the organization. It is intended that the development of information systems can provide optimal benefits to Poltekba. In this study, architectural modeling for Poltekba was carried out using The Open Group Architecture Framework (TOGAF) method which has, Architecture Development Method (ADM). TOGAF itself is a framework that provides a methodology for analyzing architecture in Poltekba as a whole. This modeling includes business architecture, information system architecture and technology architecture. The results of this study are modeling of business architecture, information system architecture and technological architecture that exist in Poltekba.
\end{abstract}

Keywords: Information Systems Architecture, Poltekba, TOGAF

\begin{abstract}
ABSTRAK
Perkembangan sistem informasi dan teknologi tidak dipungkiri menghasilkan suatu persaingan ketat terhadap para organisasi yang menggunakannya. Organisasi berlomba lomba meningkatkan teknologi yang ada untuk mempermudah aktivitasnya dan menaikkan nilai jual dari organisasi itu sendiri. Hal ini juga berlaku di dunia pendidikan, khususnya untuk perguruan tinggi. Semakin tinggi jenjang pendidikan maka semakin tinggi pula aktivitas dan kebutuhannya. Berbagai perguruan tinggi berusaha menjadi perguruan tinggi yang terbaik, hal tersebut dapat dinilai dari kualitas pendidikan yang diberikan dan tidak terlepas dari fasilitas yang ditawarkan. Untuk itu perguruan tinggi membutuhkan adanya sistem informasi dalam mengelola setiap aktivitas yang mereka jalankan, termasuk Politeknik Negeri Balikpapan (Poltekba). Namun dalam mengembangkan sebuah sistem informasi diperlukan adanya penyelarasan dengan strategi dan tujuan organisasi. Hal tersebut bertujuan agar pengembangan sistem informasi dapat memberikan manfaat yang optimal kepada Poltekba. Dalam penelitian ini dilakukan permodelan arsitektur untuk Poltekba dengan menggunakan metode The Open Group Architecture Framework (TOGAF) Architecture Development Method (ADM). TOGAF sendiri merupakan framework yang menyediakan metodologi untuk menganalisis arsitektur yang ada di Poltekba secara keseluruhan. Permodelan ini meliputi arsitektur bisnis, arsitektur sistem informasi dan arsitektur teknologi. Hasil penelitian ini adalah pemodelan dari arsitektur bisnis, arsitektur sistem informasi dan arsitektur teknologi yang ada di Poltekba.
\end{abstract}

Kata Kunci: Arsitektur Sistem Informasi, Poltekba, TOGAF 
Jurnal Inkofar * Volume 1 No. 1 Juli 2019 * ISSN: 2615-3645 (Print) / 2581-2920 (Online)

Tersedia secara online di: http://www.politeknikmeta.ac.id/meta/ojs/

\section{PENDAHULUAN}

Politeknik Negeri Balikpapan (Poltekba) adalah salah satu lembaga perguruan tinggi negeri yang menyelenggarakan pendidikan tinggi berupa politeknik dengan berbagai macam ilmu pengetahuan dan teknologi (Nasir, 2016). Poltekba mempunyai tujuan yaitu menjadi lembaga pendidikan tinggi yang memiliki karakter, unggul, dan memiliki daya saing internasional (Jamal, 2016). Dalam rangka mencapai tujuannya, Poltekba memerlukan sarana prasarana yang mendukung mahasiswa termasuk menunjang kegiatan organisasi khususnya dibidang teknologi dan informasi. Saat ini Poltekba menggunakan sistem informasi dalam menjalankan aktivitasnya. Namun, terdapat beberapa permasalahan terkait keselarasan IT dengan visi dan misi Poltekba yaitu belum terdapat kerangka dasar dalam perencanaan TI untuk memenuhi kebutuhan layanan dan juga belum terdapat model arsitektur yang terintegrasi guna menoptimalisasi sistem informasi yang ada. Karena hal tersebut, maka Poltekba memerlukan arsitektur sistem informasi (SI) untuk menyelaraskan semua sistem informasi yang digunakan.

Dalam menangani masalah terkait permodelan arsitektur SI, penulis memilih TOGAF framework sebagai metode penyelesaian masalah. Pemilihan TOGAF didasarkan pada beberapa penelitian sebelumnya. Pada penelitian pertama ditemukan bahwa dengan menggunakan TOGAF ADM peneliti dapat mengintegrasikan kebutuhan-kebutuhan informasi serta dimodelkannya arsitektur sistem informasi yang sesuai dengan visi dan misi lembaga (Syaddad, 2015). Pada penelitian kedua yang juga dilakukan pada salah satu sekolah tinggi ditemukan bahwa dengan menggunakan TOGAF ADM peneliti dapat menghasilkan rancangan model arsitektur sistem informasi yang sesuai dengan visi dan misi organisasi, serta perencanaan model arsitektur sistem informasi ini menghasilkan proses perbaikan kinerja layanan sistem informasi secara menyeluruh (Setiawan, 2015). Penelitian selanjutnya menyatakan bahwa dengan adanya enterprise srasitektur maka sistem akan terintegrasi sehingga aktivitas proses tersebut akan berjalan dengan optimal dan memudahkan pemeliharan ( ERP , et al., 2017). Oleh karena itu untuk menyusun arsitektur SI Poltekba selaku salah satu lembaga pendidikan di Indonesia, dipilih penggunaan framework TOGAF ADM sebagai metodologi penyelesaiannya.

\section{STUDI PUSTAKA}

\subsection{Arsitektur Enterprise}

Arsitektur enterprise merupakan dasar dari strategi infomasi yang juga digunakan untuk menentukan visi dan misi, apa saja informasi serta teknologi yang digunakan untuk mencapai misi tersebut serta penentuan bagaimana proses perubahan dalam mengimplementasikan teknologi yang baru berdasarkan kebutuhan (Surendro, 2009).

\subsection{TOGAF}

The Open Group Architecture Framework (TOGAF) adalah kerangka kerja yang dibuat oleh The Open Group's Architecture Framework. Mulanya TOGAF dibuat untuk Departemen Pertahanan Amerika Serikat akan tetapi seiring berjalannya waktu TOGAF mulai digunakan pada berbagai perusahaan/lembaga/organisasi. TOGAF memiliki definisi yaitu framework untuk arsitektur enterprise dimana TOGAF menyediakan metodologi untuk menganalisis arsitektur bisnis secara keseluruhan. TOGAF memiliki domain arsitektur yang merupakan bagian umum keseluruhan arsitektur enterprise. Ketiga domain tersebut yaitu Architecture, Development, Method menjelaskan bagaimana menemukan sebuah arsitektur perusahaan/lembaga/organisasi secara rinci sesuai dengan kebutuhan bisnisnya (Group, 2009).

\section{HASIL ANALISA DATA DAN PEMBAHASAN}

\subsection{Visi Arsitektur}

3.1.1. Visi

Adapun visi Politeknik Negeri Balikpapan adalah sebagai berikut:

Menjadi institusi pendidikan tinggi vokasi yang berkarakter, unggul, dan berdaya saing global.

\subsubsection{Misi}

Untuk menjalankan visi Politeknik Negeri Balikpapan maka dibuatlah misi untuk mencapai tujuan sebagai berikut:

- $\quad$ Menyelenggarakan dan mengembangkan pendidikan tinggi vokasi yang bermutu, relevan, dan berdaya saing tinggi melalui pelaksanaan pendidikan, penelitian dan pengabdian kepada 
masyarakat, yang didukung dengan kurikulum dan sumber daya pendidikan yang sesuai dengan standar yang berlaku;

- $\quad$ Menyelenggarakan manajemen kelembagaan yang efisien, produktif, akuntabel, dan transparan serta berkeadilan untuk menjamin terselenggaranya pelayanan prima dan meningkatnya kepercayaan publik;

- Mengembangkan dan menghasilkan karya dan produk intelektual yang inovatif.

\subsubsection{Strategi}

Strategi dalam rangka mencapai visi dan misi Politeknik Negeri Balikpapan menyusun:

Rencana Induk Pengembangan yang memuat rencana dan program pengembangan 25 (dua puluh lima) tahun.

Rencana Strategis memuat rencana dan program 5 (lima) sampai dengan 10 (sepuluh) tahun.

Rencana Operasional atau Rencana Kerja Tahunan merupakan penjabaran dari Rencana Strategis yang memuat program dan kegiatan selama 1 (satu) tahun.

\subsubsection{Tujuan}

Tujuan penyusunan Politeknik Negeri Balikpapan adalah memberikan arah dan pedoman bagi kegiatan penelitian, pengembangan serta implementasi hasil atau produk penelitian. Dengan memanfaatkan sumber daya yaitu dosen, pusat penelitian, pusat kajian, dan fasilitas serta dana yang tersedia, hasil penelitian berupa produk dan hasil nyata yang bermanfaat bagi masyarakat, industri dan stakeholder serta mendukung kebutuhan nasional dan dapat membantu mengatasi permasalahan bangsa.

\subsubsection{Objektif Terkait Informasi}

Pada Politeknik Negeri memiliki objektif terkait Sistem Informasi untuk mendukung proses bisnis adalah sebagai berikut:

1. Menghasilkan Mahasiswa yang bermutu diukur dari jumlah peminat, proporsi pendaftar terhadap daya tampung, proporsi diterima, dan registrasi.

2. Mengembangkan civitas akademika yang inovatif, responsif, kreatif, terampil, berdaya saing, dan kooperatif melalui pelaksanaan Tridharma.

3. Memiliki Catatan Prestasi Mahasiswa yang meliputi: IPK, Lama Studi, Mahasiswa Drop Out/Mengundurkan Diri, Reputasi Bidang Akademik dan Profesi, serta Bakat dan Minat.

4. Memiliki Profil Lulusan dan Masa Tunggu Lulusan dalam memperoleh pekerjaan pertama dan kesesuaian dengan kompetensiMemiliki Rekaman Data Lulusan untuk perbaikan aspek proses pembelajaran, penggalangan dana, dan informasi pekerjaan.

5. Memiliki Pedoman dan Pelaksanaan Monitoring dan Evaluasi Kinerja Dosen dan Tenaga Kependidikan.

6. Memiliki Profil Dosen Tetap dan Tidak Tetap dengan cakupan tingkat pendidikan, jabatan, akademik, dan bidang keahlian.

7. Mempunyai Data Pencapaian prestasi/reputasi/rekognisi dosen di tingkat lokal, wilayah (provinsi), nasional, atau internasional.

8. Memiliki Sistem Pembelajaran, Pelaksanaan Proses Pembelajaran, dan Evaluasi Pembelajaran.

9. Memiliki Sistem Pembimbingan Akademik.

10. Memiliki Data Penggunaan Dana dan rata-rata dana untuk Operasional Mahasiswa penelitian Dosen Tetap dan Pengabdian Masyarakat.

11. Memiliki Sistem Informasi dan fasilitas yang digunakan dalam proses pembelajaran.

12. Memiliki Data Jumlah Penelitian, Artikel Ilmiah, dan Pengabdian Masyarakat Dosen Tetap dan Tidak Tetap dengan keterlibatan Mahasiswa.

13. Adanya Kegiatan Kerjasama dengan institusi di dalam dan di luar negeri dalam 3 tahun terakhir.

14. Memiliki Sistem Pengelolaan Fungsional dan Operasional program studi.

15. Memiliki Sistem rekrutmen dan seleksi calon Mahasiswa.

\subsection{Arsitektur Bisnis}

Terdapat 13 departemen di Poltekba yang memiliki proses bisnis berbeda sesuai dengan fungsi bisnisnya masing-masing. Adapun proses umum yang terdapat pada Poltekba dapat dilihat pada Gambar 1 (Atrinawati \& Lois, 2018). 


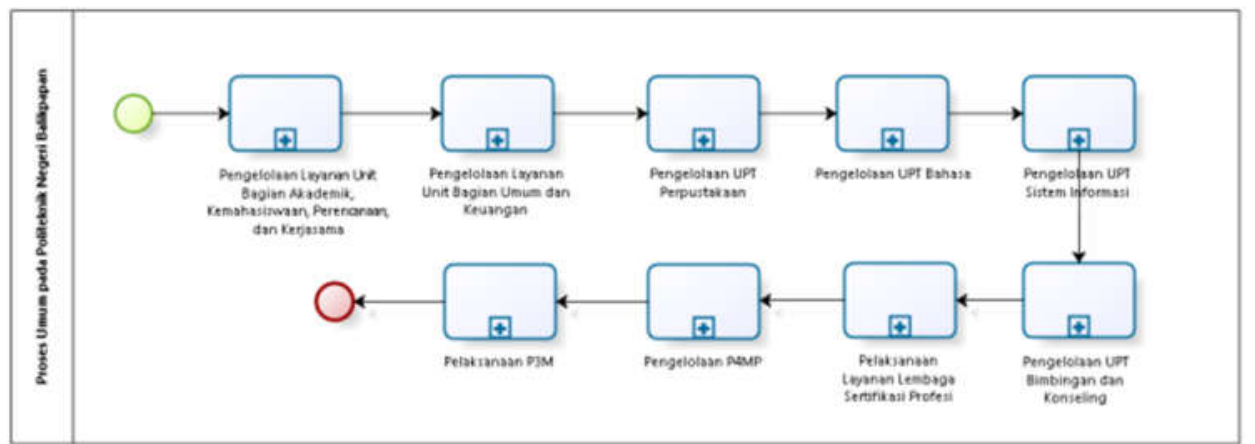

Gambar 1. Proses Umum Polteknik Negeri Balikpapan

\subsubsection{Proses Umum Unit Subbagian Akademik dan Kemahasiswaan}

Subbagian Akademik dan Kemahasiswaan mempunyai tugas melakukan urusan layanan pendidikan, penelitian, pengabdian kepada masyarakat, registrasi, pembinaan minat, bakat, penalaran, dan kesejahteraan mahasiswa serta alumni. Proses umum subbagian akademik dan kemahasiswaan adalah menyusun rencana operasional, mengevaluasi pelaksanaan kegiatan pendidikan dan pengajaran, penelitian, dan pengabdian kepada masyarakat, mempersiapkan program pendidikan baru, melaksanakan tugas harian ketua, bila ketua berhalangan, serta menyusun laporan kegiatan dan bertanggung jawab kepada Ketua.

\subsubsection{Proses Umum Unit Subbagian Perencanaan dan Kerjasama}

Subbagian Perencanaan dan Kerja sama mempunyai tugas melakukan urusan pengumpulan, pengolahan, dan penyajian data dan informasi, penyusunan rencana program, dan anggaran serta administrasi kegiatan Subbagian Perencanaan dan Kerja Sama. Proses umum pada subbagian perencanaan dan kerjasama Poltekba adalah melaksanakan analisa data perencanaan, menyusun dokumen perencanaan, membuat dokumen perencanaan, membuat dokumen pelaksanaan, mengevaluasi dan monitoring jalannya pelaksanaan serta menyusun laporan pelaksanaan

\subsubsection{Proses Umum Unit Subbagian Umum}

Subbagian Umum mempunyai tugas melakukan urusan persuratan, kearsipan, dokumentasi, keamanan, ketertiban, kebersihan, keindahan keprotokolan, hukum, organisasi, ketatalaksanaan, hubungan masyarakat, dan pengelolaan Barang Milik Negara di lingkungan Poltekba.

\subsubsection{Proses Umum Unit Subbagian Keuangan dan Kepegawaian}

Subbagian Keuangan dan kepegawaian mempunyai tugas melakukan urusan pembiayaan, penerimaan, penyimpanan, pembayaran, dan pertanggungjawaban anggaran serta penyusunan rencana pengadaan, pengangkatan, mutasi, pengembangan, disiplin dan pemberhentian pegawai di lingkungan Poltekba.

\subsubsection{Proses Umum UPT Perpustakaan}

UPT Perpustakaan merupakan unit pelaksana teknis di bidang perpustakaan yang mempunyai tugas melaksanakan pemberian layanan kepustakaan untuk keperluan pendidikan, penelitian, dan pengabdian kepada masyarakat. Proses umum UPT perpustakaan di Poltekba adalah merencanakan program kebutuhan buku-buku atau bahan bacaan perpustakaan, melaksanakan pengadaan buku-buku dan bahan bacaan perpustakaan, melaksanakan katalogasi buku-buku dan bahan bacaan yang ada dan mengatur sirkulasi buku-buku.

\subsubsection{Proses Umum UPT Bahasa}

UPT Bahasa merupakan unit pelaksana teknis di bidang pengembangan pembelajaran dan layanan kebahasaan yang mempunyai tugas melaksanakan pengembangan pembelajaran, peningkatan kemampuan, dan tes bahasa. Proses umum dari UPT bahasa di Poltekba adalah mengadakan fasilitas UPT sebagai penunjang pembelajaran dalam mewujudkan tujuan departemen, mengadakan proses pembelajaran bahasa baik itu bahasa inggris maupun bahasa Indonesia serta cara berkomunikasi yang benar dan mengevaluasi proses pembelajaran

\subsubsection{Proses Umum UPT Sistem Informasi}

UPT Sistem Informasi atau UPT SI merupakan unit pelaksana teknis di bidang teknologi informasi dan jaringan sistem informasi. Kepala UPT Sistem Informasi mempunyai tugas melaksanakan 
pengembangan, pengelolaan, pemeliharaan jaringan dan sistem informasi serta pemberian layanan Teknologi Informasi untuk kepentingan pendidikan, penelitian, dan pengabdian kepada masyarakat.

\subsubsection{Proses Umum UPT Bimbingan dan Konseling}

UPT Bimbingan dan Konseling merupakan unit pelaksana teknis di bidang layanan konsultasi. Ketua UPT Bimbingan dan Konseling mempunyai tugas melaksanakan memberikan layanan konsultasi kepada dosen, mahasiswa, pegawai, dan masyarakat. Proses umum UPT bimbingan dan konseling di Politaknik Ngeri Balikpapan adalah merencanakan program kegiatan bimbingan konseling dan melaksanakan program pemberian pelayanan bimbingan konseling.

\subsubsection{Proses Umum Lembaga Sertifikasi Profesi}

Lembaga Sertifikasi Profesi (LSP) merupakan unit pelaksana sertifikasi baik dosen maupun mahasiswa. Proses umum lembaga sertifikasi profesi pada Poltekba adalah mengkoordinir dan mengelola tempat uji kompetensi, menyusun rencana pengembangan sertifikasi dosen serta menyelenggarakan sertifikasi kompetensi mahasiswa

\subsubsection{Proses Umum P4MP}

Pusat Pengembangan Pembelajaran dan Penjaminan Mutu Pendidikan (P4MP) mempunyai tugas melaksanakan, mengkoordinasikan, memantau, dan menilai pelaksanaan kegiatan pengembangan pembelajaran dan penjaminan mutu pendidikan. Proses umum pusat pengembangan pembelajaran dan penjaminan mutu pendidikan di Poltekba adalah menyusun rencana, program dan anggaran P4MP, melakukan pengembangan pembelajaran, mengembangkan sistem penjaminan mutu pendidikan, melaksanakan penjaminan mutu pendidikan dan administrasi P4MP.

\subsubsection{Proses Umum P3M}

Pusat Penelitian dan Pengabdian kepada Masyarakat (P3M) mempunyai tugas melaksanakan, mengkoordinasikan, memantau, dan menilai pelaksanaan kegiatan penelitian dan pengabdian kepada masyarakat. Proses umum pusat penelitian dan pengabdian masyarakat di Poltekba adalah menyusun rencana, program dan anggaran P3M, melaksanakan penelitian ilmiah, melaksanakan pengabdian.

\subsection{Arsitektur Sistem Informasi}

\subsubsection{Arsitektur Data}

Setelah entitas data dari setiap proses bisnis telah dipetakan, maka dilakukan penyusunan relasi antara entitas data dengan proses bisnis untuk menggambarkan keterlibatan proses bisnis dalam melakukan modifikasi terhadap entitas data tersebur seperti create, update, dan retrieved. Nilai untuk setiap cell matriks diisi dengan ketentuan, yaitu $\mathrm{C}$ (Create) yang memiliki arti bahwa proses bisnis terlibat dalam pembuatan, pemutakhiran, dan penggunaan entitas data. U (Update) yang memiliki arti bahwa proses bisnis terlibat dalam pemutakhiran, penghapusan, dan penggunaan entitas data. R (Retrieved) yang memiliki arti bahwa proses bisnis terlibat dalam penggunaan entitas data.

\subsubsection{Arsitektur Aplikasi}

Tujuan yang hendak dicapai dalam tahap ini adalah mendefinisikan jenis-jenis sistem aplikasi yang relevan dengan enterprise dan apa yang dilakukan aplikasi-aplikasi dalam mengelola data dan mempresentasikan informasi ke manusia dan sistem lain pada organisasi. Sasaran arsitektur sistem informasi pada aplikasi ini adalah mendefinisikan jenis-jenis utama sistem aplikasi (yaitu sistem informasi-sistem informasi) yang diperlukan untuk mengolah data dan mendukung bisnis dan menyatakan aplikasi sebagai kelompok kapabilitas yang mengelola objek-objek data di arsitektur informasi dan mendukung fungsi-fungsi bisnis di arsitektur bisnis. Adapun deskripsi dari sistem informasi yang ada di Poltekba bisa dilihat pada Tabel 1.

Tabel 1. Sistem informasi saat ini di Poltekba

\begin{tabular}{|c|c|c|c|c|c|}
\hline $\begin{array}{l}\text { Sistem } \\
\text { Informasi }\end{array}$ & $\begin{array}{l}\text { Blended } \\
\text { Learning }\end{array}$ & $\begin{array}{c}\text { Sistem } \\
\text { Informasi } \\
\text { Kepegawaian }\end{array}$ & Jurnal Online & SIAMI & $\begin{array}{l}\text { Penomoran } \\
\text { Surat dan SK }\end{array}$ \\
\hline Deskripsi & $\begin{array}{l}\text { Blended } \\
\text { Learning } \\
\text { Poltekba } \\
\text { Sistem } \\
\text { informasi yang } \\
\text { digunakan }\end{array}$ & $\begin{array}{l}\text { Sistem } \\
\text { informasi } \\
\text { yang } \\
\text { digunakan } \\
\text { oleh unit } \\
\text { keuangan dan }\end{array}$ & $\begin{array}{l}\text { Jurnal Online } \\
\text { Poltekba } \\
\text { adalah sistem } \\
\text { penerbitan } \\
\text { online } \\
\text { berbasis }\end{array}$ & $\begin{array}{l}\text { Sistem } \\
\text { informasi } \\
\text { yang } \\
\text { digunakan } \\
\text { untuk } \\
\text { melacak para }\end{array}$ & $\begin{array}{l}\text { Aplikasi yang } \\
\text { digunakan } \\
\text { untuk } \\
\text { memberikan } \\
\text { penomoran } \\
\text { surat yang }\end{array}$ \\
\hline
\end{tabular}


Jurnal Inkofar * Volume 1 No. 1 Juli 2019 * ISSN: 2615-3645 (Print) / 2581-2920 (Online)

Tersedia secara online di: http://www.politeknikmeta.ac.id/meta/ojs/

\begin{tabular}{|c|c|c|c|c|c|}
\hline $\begin{array}{l}\text { Sistem } \\
\text { Informasi }\end{array}$ & $\begin{array}{l}\text { Blended } \\
\text { Learning }\end{array}$ & $\begin{array}{c}\text { Sistem } \\
\text { Informasi } \\
\text { Kepegawaian }\end{array}$ & Jurnal Online & SIAMI & $\begin{array}{l}\text { Penomoran } \\
\text { Surat dan SK }\end{array}$ \\
\hline & $\begin{array}{l}\text { untuk kegiatan } \\
\text { perkuliahan } \\
\text { dilakukan di } \\
\text { dalam sistem } \\
\text { informasi. }\end{array}$ & $\begin{array}{l}\text { kepegawaian } \\
\text { untuk } \\
\text { mencatat } \\
\text { selurh data - } \\
\text { data pegawai } \\
\text { yang ada di } \\
\text { Poltekba }\end{array}$ & $\begin{array}{l}\text { Open Journal } \\
\text { System } \\
\text { (OJS). }\end{array}$ & $\begin{array}{l}\text { alumni } \\
\text { mengenai } \\
\text { pekerjaan dan } \\
\text { gaji serta } \\
\text { mendata } \\
\text { alumni. }\end{array}$ & $\begin{array}{l}\text { akan } \\
\text { dikeluarkan } \\
\text { oleh Poltekba }\end{array}$ \\
\hline $\begin{array}{l}\text { Pengemba } \\
\text { ng } \\
\text { aplikasi }\end{array}$ & $\begin{array}{l}\text { Poltek } \\
\text { Balikpapan } \\
\text { dan Poltek } \\
\text { Jakarta }\end{array}$ & $\begin{array}{l}\text { Poltek } \\
\text { Balikpapan } \\
\text { dan Poltek } \\
\text { Surabaya }\end{array}$ & $\begin{array}{l}\text { Poltek } \\
\text { Balikpapan }\end{array}$ & $\begin{array}{l}\text { Poltek } \\
\text { Balikpapan }\end{array}$ & $\begin{array}{l}\text { Poltek } \\
\text { Balikpapan }\end{array}$ \\
\hline $\begin{array}{l}\text { Unit } \\
\text { organisasi }\end{array}$ & UPT SI & $\begin{array}{l}\text { Unit } \\
\text { Keuangan dan } \\
\text { Kepegawaian }\end{array}$ & P3M & $\begin{array}{l}\text { UPT } \\
\text { Bimbingan } \\
\text { dan } \\
\text { Konseling } \\
\end{array}$ & $\begin{array}{l}\text { Bagian Umum } \\
\text { dan Keuangan }\end{array}$ \\
\hline Pengguna & $\begin{array}{l}\text { Mahasiswa dan } \\
\text { dosen }\end{array}$ & $\begin{array}{l}\text { Pegawai yang } \\
\text { terdiri dari } \\
\text { dosen, tenaga } \\
\text { pendidik dan } \\
\text { staf }\end{array}$ & $\begin{array}{l}\text { Mahasiswa } \\
\text { dan Dosen }\end{array}$ & $\begin{array}{l}\text { UPT } \\
\text { Bimbingan } \\
\text { dan } \\
\text { Konseling }\end{array}$ & $\begin{array}{l}\text { Sub Bagian } \\
\text { Umum dan } \\
\text { Sub Bagian } \\
\text { Keungan dan } \\
\text { Kepegawaian }\end{array}$ \\
\hline $\begin{array}{l}\text { Jenis } \\
\text { pengguna } \\
\text { an } \\
\end{array}$ & $\begin{array}{l}\text { Online dan } \\
\text { offline }\end{array}$ & $\begin{array}{l}\text { Offline } \\
\text { menggunakan } \\
\text { intranet }\end{array}$ & $\begin{array}{l}\text { Online dan } \\
\text { offlline }\end{array}$ & $\begin{array}{l}\text { Online dan } \\
\text { offline }\end{array}$ & Offline \\
\hline $\begin{array}{l}\text { Operasion } \\
\text { al } \\
\text { Aplikasi }\end{array}$ & Multi user & Multi user & Multi user & Single user & Single user \\
\hline Modul & $\begin{array}{l}\text { Menampilkan } \\
\text { berita } \\
\text { perkuliahan, } \\
\text { Membuat soal } \\
\text { uts dan uas, } \\
\text { Membuat } \\
\text { portal } \\
\text { pengumpulan } \\
\text { tugas }\end{array}$ & $\begin{array}{l}\text { Mendata } \\
\text { pegawai, } \\
\text { Merekap } \\
\text { absensi } \\
\text { pegawai } \\
\text { poltekba, } \\
\text { Merekap } \\
\text { tunjangan, } \\
\text { Remunisasi } \\
\text { PNS untuk } \\
\text { menghitung } \\
\text { integritas } \\
\text { kinerja }\end{array}$ & $\begin{array}{l}\text { Membuat dan } \\
\text { me-manage } \\
\text { jurnal, } \\
\text { Membaca } \\
\text { jurnal, } \\
\text { Mereview } \\
\text { jurnal, } \\
\text { Mengupload } \\
\text { jurnal untuk } \\
\text { publikasi }\end{array}$ & $\begin{array}{l}\text { Memberikan } \\
\text { informasi dan } \\
\text { link } \\
\text { pekerjaan } \\
\text { pada alumni, } \\
\text { Memberikan } \\
\text { informasi dan } \\
\text { layanan } \\
\text { pendidikan } \\
\text { lanjut, } \\
\text { Menyimpan } \\
\text { data alumni }\end{array}$ & $\begin{array}{l}\text { Memberikan } \\
\text { penomoran } \\
\text { surat sesuai } \\
\text { dengan } \\
\text { dokumen yang } \\
\text { akan } \\
\text { dikeluarkan }\end{array}$ \\
\hline Pengelola & UPT SI & $\begin{array}{l}\text { UPT SI dan } \\
\text { Sub Bagian } \\
\text { Keungan dan } \\
\text { Kepegawain }\end{array}$ & $\begin{array}{l}\text { UPT SI dan } \\
\text { P3M }\end{array}$ & UPT SI & UPT SI \\
\hline $\begin{array}{l}\text { Waktu } \\
\text { Pengguna } \\
\text { an }\end{array}$ & 24 Jam & $24 \mathrm{Jam}$ & 24 Jam & 24 Jam & 24 Jam \\
\hline $\begin{array}{l}\text { Sistem } \\
\text { terkait }\end{array}$ & Tidak ada & Tidak ada & $\begin{array}{l}\text { Open Journal } \\
\text { System }\end{array}$ & Tidak ada & Tidak ada \\
\hline Database & MySQL & MySQL & MySQL & MySQL & Oracle \\
\hline $\begin{array}{l}\text { Isu jangka } \\
\text { panjang }\end{array}$ & $\begin{array}{l}\text { Akan } \\
\text { dikembangkan }\end{array}$ & $\begin{array}{l}\text { Akan } \\
\text { dikembangkan }\end{array}$ & $\begin{array}{l}\text { Belum ada } \\
\text { isu jangka }\end{array}$ & $\begin{array}{l}\text { Belum ada } \\
\text { isu jangka }\end{array}$ & $\begin{array}{l}\text { Sudah sesuai } \\
\text { dengan fungsi }\end{array}$ \\
\hline
\end{tabular}


Jurnal Inkofar * Volume 1 No. 1 Juli 2019 * ISSN: 2615-3645 (Print) / 2581-2920 (Online)

Tersedia secara online di: http://www.politeknikmeta.ac.id/meta/ojs/

\begin{tabular}{clllll}
\hline $\begin{array}{c}\text { Sistem } \\
\text { Informasi }\end{array}$ & $\begin{array}{c}\text { Blended } \\
\text { Learning }\end{array}$ & $\begin{array}{c}\text { Sistem } \\
\text { Informasi } \\
\text { Kepegawaian }\end{array}$ & Jurnal Online & SIAMI & $\begin{array}{c}\text { Penomoran } \\
\text { Surat dan SK }\end{array}$ \\
\hline & fiturnya & jika ada & panjang pada & panjang & pada aplikasi. \\
mengikuti & perubahan & system & & \\
pekembangan & proses yang & informasi ini & & \\
teknologi & berpengaruh & karena sudah & & \\
informasi. & pada system. & dirancang & \\
& & sebagai & & \\
& & mana. & \\
\hline
\end{tabular}

Selain sistem-sistem yang telah ada Politeknik Negeri Balikapapan juga memiliki sistem yang akan diajukan dimasa yang akan datang. Adapun deskripsi untuk sistem yang sedang direncanakan untuk masa mendatang dapat dilihat pada Tabel 2.

Tabel 2. Sistem informasi yang direncanakan

\begin{tabular}{lll}
\hline \multicolumn{1}{c}{$\begin{array}{c}\text { Kandidat } \\
\text { Aplikasi }\end{array}$} & \multicolumn{1}{c}{ Definisi } & \multicolumn{1}{c}{ Entitas Data } \\
\hline $\begin{array}{l}\text { Sistem } \\
\text { Informasi } \\
\text { Akademik }\end{array}$ & $\begin{array}{l}\text { Mengelola segala hal } \\
\text { terkait kegiatan } \\
\text { akademik Poltekba }\end{array}$ & $\begin{array}{l}\text { Data Dosen Pengajar Mata Kuliah, Data } \\
\text { Komponen Nilai Mata Kuliah, Konversi Nilai } \\
\text { Mata Kuliah, Keuangan Mahasiswa, Data } \\
\text { Referensi DIKTI, Back up Data, Dan data } \\
\text { penunjang lainnya }\end{array}$ \\
\hline $\begin{array}{l}\text { Sistem } \\
\text { Informasi }\end{array}$ & $\begin{array}{l}\text { Mengelola segala hal } \\
\text { terkait sistem yang ada } \\
\text { di perpustakaan }\end{array}$ & $\begin{array}{l}\text { Data Daftar Pustaka Buku. Data Anggota. Data } \\
\text { Layanan Transaksi Sirkulasi, Data Pengadaan } \\
\text { Pustaka, Data Buku Tamu, Digital Library }\end{array}$ \\
\hline $\begin{array}{l}\text { Sistem } \\
\text { Informasi }\end{array}$ & $\begin{array}{l}\text { Mengelola hal terkait } \\
\text { pembelajaran bahasa } \\
\text { secara offline maupun } \\
\text { Bahline. }\end{array}$ & $\begin{array}{l}\text { Digital Learning, TOEFL dan IELTS, Sertifikasi, } \\
\text { Dokumen Lapaoran Kegiatan, Database UPT }\end{array}$ \\
\hline Sistem & $\begin{array}{l}\text { Mengelola hal terkait } \\
\text { kegiatan sertifikasi } \\
\text { profesi yang ada di } \\
\text { Poltekba }\end{array}$ & $\begin{array}{l}\text { Data Master (Data Asesor, Data Mahasiswa dan } \\
\text { Mitra, TUK dan Skema.), Data Transaski, } \\
\text { Dokumen Laporan, Dokumen Hasil Sertifikasi, } \\
\text { Dokumen Rekap Asesman }\end{array}$ \\
\hline
\end{tabular}

\subsection{Arsitektur Teknologi}

\subsubsection{Konfigurasi Software dan Hardware}

Pada Poltekba menggunakan beberapa software dalam mengoperasikan sistem informasi yang ada. Adapun sever yang digunakan oleh Poltekba adalah CMS Module Webserver berupa Apache Versi 2.2.22, PHP Versi 5.3.10-1, MySQL Versi 5.5.28. Radio server yaitu Ubuntu 12.04.1 LTS. DBMS berupa My SQL, ORACLE. Dan Windows 7 sebagai operating system. Untuk penggunaan hardware sendiri, Poltekba juga memiliki beberapa perangkat yang digunakan sebagai server, processor, RAM, storage, input dan output. Adapun spesifikasi server yaitu Dell Optiplex 380. Processor berupa Intel ${ }^{\circledR}$ Core $^{\mathrm{TM}}$ i3 CPU M 370 dengan RAM sebesar 4 GB, 8GB dan storage sebesar 49.6 GB - 1 TB. Input device yang dimiliki berupa mouse, keyboard, scanner, Silent Panic Button, Emergency Panic Button, camera CCTV. Output device berupa monitor LCD dan printer (Laser, Ink).

\subsubsection{Konfigurasi Network}

Topologi jaringan Poltekba dilihat dari sudut pandang luar yang luas dimana didefinisikan setiap satuan komponen hardware jaringannya dengan dilakukan split dengan persegi yang menandai bagian tertentu misalnya pada bagian divisi rektorat, lab elektro, TMAB, Server Farm dan Management FPS. Dan objek yang berbentuk awan adalah cloud yang terdapat sebanyak 3 yaitu dari SPEEDY, ASTINET dan PSTN. Adapun gambaran topologi jaringan Poltekba dapat dilihat pada Gambar 2. 


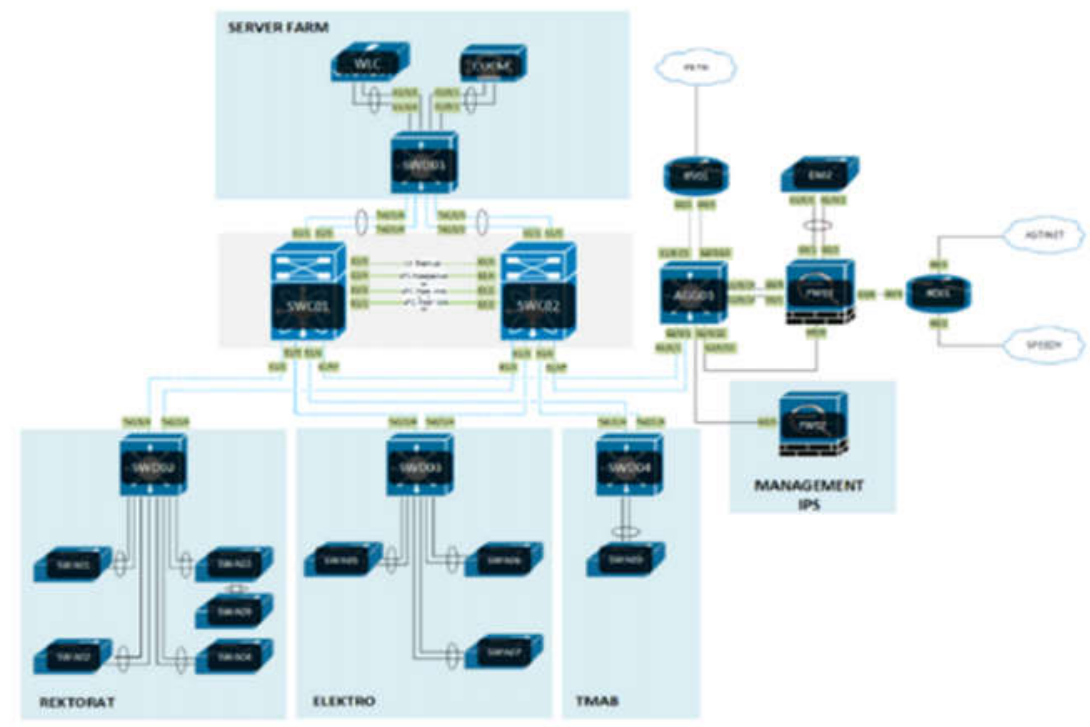

Gambar 2. Topologi jaringan Poltekba

\subsection{Peluang dan Solusi}

Pada tahap ini langkah awal yang dilakukan adalah mengidentifikasi proses binsis yang membutuhkan dukungan dari sistem informasi. Adapun prioritas skala pengembangan aplikasi yang ada, dapat dilihat pada Tabel 3 .

Tabel 3. Prioritas skala pengembangan aplikasi

\begin{tabular}{lccccc}
\hline Aplikasi & Demand Risk & $\begin{array}{c}\text { Potenti } \\
\text { al } \\
\text { Benefit }\end{array}$ & $\begin{array}{c}\text { Organizationa } \\
\text { I Impact }\end{array}$ & Nilai \\
\hline Blended Learning Poltekba (BLP) & 3 & 4 & 3 & 3 & 13 \\
\hline Sistem Informasi Kepegawaian & 4 & 3 & 4 & 4 & 15 \\
\hline E - Jurnal & 3 & 4 & 3 & 2 & 12 \\
\hline SIAMI & 4 & 3 & 4 & 4 & 15 \\
\hline $\begin{array}{l}\text { Penomoran Surat dan Dokumen } \\
\text { SK }\end{array}$ & 2 & 2 & 3 & 3 & 10 \\
\hline Sistem Informasi Akademik & 4 & 3 & 4 & 4 & 15 \\
\hline Sistem Informasi Perpustakaan & 2 & 2 & 3 & 3 & 10 \\
\hline Sistem Informasi Bahasa & 2 & 3 & 3 & 3 & 11 \\
\hline Sistem Informasi LSP & 2 & 3 & 3 & 3 & 11 \\
\hline Sistem informasi pembuatan & 2 & 2 & 3 & 4 & 11 \\
RKAKL & & & & & \\
\hline
\end{tabular}

Adapun ruang lingkup pengembangan sistem informasi dapat dilihat pada Tabel 4.

Tabel 4. Ruang lingkup pengembangan sistem informasi

\begin{tabular}{lllll}
\hline No & $\begin{array}{c}\text { Sistem } \\
\text { Informasi }\end{array}$ & \multicolumn{1}{c}{ Functional Requirement } & Pengguna & $\begin{array}{c}\text { Software } \\
\text { sejenis }\end{array}$ \\
\hline & & Untuk memudahkan seluruh \\
& departemen baik unit bagian, & Seluruh unit & \\
& Sistem & subbagian, UPT atau pusat & departemen di & Aplikasi \\
\multirow{2}{*}{1} & informasi & dalam mengintegrasikan seluruh & Politeknik & RKAKL \\
& pembuatan & RistekDikt \\
& RKAKL & entitas yang terkait dalam satu & Negeri & i \\
& & sistem secara linear dalam & Balikapapan & \\
\hline
\end{tabular}


Jurnal Inkofar * Volume 1 No. 1 Juli 2019 * ISSN: 2615-3645 (Print) / 2581-2920 (Online)

Tersedia secara online di: http://www.politeknikmeta.ac.id/meta/ojs/

\begin{tabular}{|c|c|c|c|c|}
\hline 2 & $\begin{array}{l}\text { Sistem } \\
\text { informasi } \\
\text { pendataan } \\
\text { buku tamu } \\
\text { perpustakaa } \\
\text { n }\end{array}$ & $\begin{array}{l}\text { Untuk mempermudah pendataan } \\
\text { tamu dalam perpustakaan } \\
\text { dengan cara mengintegrasikan } \\
\text { seluruh informasi tamu dengan } \\
\text { menggunakan kartu pengenal. }\end{array}$ & $\begin{array}{l}\text { Seluruh civitas } \\
\text { akademik } \\
\text { Poltekba }\end{array}$ & E-Library \\
\hline 3 & $\begin{array}{l}\text { Sistem } \\
\text { Informasi } \\
\text { Akademik }\end{array}$ & $\begin{array}{l}\text { Mengelola segala hal terkait } \\
\text { kegiatan akademik dan sistem } \\
\text { yang mendukung kegiatan } \\
\text { akademik Poltekba }\end{array}$ & $\begin{array}{l}\text { Seluruh civitas } \\
\text { akademik } \\
\text { Poltekba }\end{array}$ & $\begin{array}{l}\text { SIKANTA } \\
\mathrm{N}\end{array}$ \\
\hline 4 & $\begin{array}{l}\text { Sistem } \\
\text { Informasi } \\
\text { Bahasa }\end{array}$ & $\begin{array}{l}\text { Mengelola hal terkait } \\
\text { pembelajaran bahasa secara } \\
\text { offline maupun online dalam } \\
\text { bentuk digital yang bersifat easy } \\
\text { to use. }\end{array}$ & $\begin{array}{l}\text { Seluruh civitas } \\
\text { akademik } \\
\text { Poltekba }\end{array}$ & Neo Study \\
\hline 5 & $\begin{array}{l}\text { Sistem } \\
\text { Informasi } \\
\text { LSM }\end{array}$ & $\begin{array}{l}\text { Mengelola hal terkait kegiatan } \\
\text { sertifikasi profesi yang ada di } \\
\text { POLTEKBA. }\end{array}$ & $\begin{array}{l}\text { Seluruh civitas } \\
\text { akademik } \\
\text { Poltekba }\end{array}$ & $\begin{array}{l}\text { JobStreet.c } \\
\text { om }\end{array}$ \\
\hline
\end{tabular}

\section{KESIMPULAN}

Dalam melakukan desain untuk arsitektur SI/TI di Poltekba, hal yang pertama dilakukan adalah mengetahui visi dan misi Poltekba, menentukan strategi, tujuan dan objektif terkait sistem informasi yang berguna untuk mengukur apa saja yang ingin dicapai dengan adanya asitektur SI/TI.

Dalam memodelkan arsitektu bisnis yang ada di Poltekba, digunakan alat bantu yaitu Business Process Model Nation (BPMN). Permodelan ini menghasilkan 11 model proses bisnis yang ada di Poltekba. Dalam memodelkan arsitektur sistem informasi yang ada di Poltekba menghasilkan dua arsitektur yaitu arsitektur data dan arsitektur aplikasi. Arsitektur data menghasilkan identifikasi terkait pemetaan entitas data. Sementara arstektur aplikasi menghasilkan deskripsi setiap aplikasi yang sedang digunakan maupun aplikasi yang dirancang untuk masa mendatang. Dalam memodelkan arsitektur teknologi yang ada di Poltekba menghasilkan konfigurasi dari hardware dan software yang digunakan di Poltekba. Serta model jaringan yang juga sedang digunakan di Poltekba.

\section{DAFTAR PUSTAKA}

ERP , D., Sulaeman , Y. \& Achadi, N., 2017. Arsitektur Enterprise Sistem Informasi Centralized Traffic Control (Ctc) Kereta Api. Jurnal Inkofar, p. 11.

Atrinawati, L. H. \& Lois, G. A., 2018. Modeling Academic Business Process for Balikpapan State Polytechnic using BPMN. Balikpapan, s.n., pp. 96-101.

Group, T. O., 2009. Togaf Version 9. San Fransisco: The Open Group.

Jamal, N., 2016. Rencana Strategis Politeknik Negeri Balikpapan Tahun 2015-2019. Balikpapan: Politeknik Negeri Balikpapan.

Nasir, M., 2016. Peraturan Menteri Riset, Teknologi, Dan Pendidikan Tinggirepublik Indonesianomor 9 Tahun 2016tentangstatuta Politeknik Negeri Balikpapan. Jakarta: Kementrian Riset, Teknologi dan Pendidikan Tinggi RI.

Setiawan, R., 2015. Perancangan Arsitektur Enterprise untuk Perguruan Tinggi Swasta Menggunakan TOGAF ADM. Jurnal Algoritma Sekolah Tinggi Teknologi Garut , p. 549.

Surendro, K., 2009. Pengembangan Rencana Induk Sistem Informasi. Bandung: Informatika.

Syaddad, H. N., 2015. Perancangan Model Arsitektur Sistem Informasi Di Perguruan Tinggi Menggunakan Togaf Architecture Development Methode (Adm) (Studi Kasus: Universitas Suryakancana). Media Jurnal Informatika, p. 26.

\section{UCAPAN TERIMA KASIH}

Penulis mengucapkan terima kasih kepada Kementrian Riset, Teknologi, dan Pendidikan Tinggi atas bantuan biaya dari Penelitian Dosen Pemula Kementrian Riset, Teknologi, dan Pendidikan Tinggi tahun 2019 sehingga penelitian dapat terlaksana. Penulis juga mengucapkan terima kasih kepada Politeknik Negeri Balikpapan yang telah bekerja sama selama penelitian berlangsung. 